\title{
Norma i uzus $w$ dydaktyce przekładu specjalistycznego wobec oczekiwań rynku pracy
}

\author{
Matgorzata Jokiel \\ INSTYTUT FILOLOGII GERMAŃSKIEJ, UNIWERSYTET OPOLSKI \\ PL. STASZICA 1, 45-052 OPOLE \\ mjokiel@uni.opole.pl
}

\begin{abstract}
The author focuses on issues related to university teaching of interpretation and translation: consecutive interpretation and sight translation in respect of a specialist language, in particular the economic one. The starting point for further considerations is the presentation of the characteristics of the above-mentioned specialist language and the question regarding the role and importance of specialist knowledge and quality criteria in the process of interpretation and translation teaching. From the viewpoint of author's own teaching and practical experience, an attempt is made to diversify priorities, goals and methodological approaches in relation to the abovementioned forms of interpretation and translation. Market requirements and expectations of potential employers, resulting from job advertisements, become of a particular importance in this context, as they need to be taken into consideration in order to optimize teaching of interpretation and translation.
\end{abstract}

\section{Wprowadzenie: norma a uzus w dydaktyce przekładu}

Poniższe rozważania poświęcone są specyfice dydaktyki akademickiej tłumaczenia ustnego $\mathrm{w}$ rejestrach specjalistycznych - w szczególności $\mathrm{z}$ zakresu ekonomii - $\mathrm{z}$ uwzględnieniem dwóch form przekładu: konsekutywnego oraz a vista. Biorąc za punkt wyjścia krótką charakterystykę języka ekonomicznego z perspektywy przekładoznawczej, na podstawie własnego doświadczenia dydaktycznego oraz translatorskiego (uzus), autorka podejmuje próbę zróżnicowania wymogów, celów i metodyki postępowania w przypadku wspomnianych form translacji ustnej, zarówno przy uwzględnieniu ich specyfiki, jak i uwarunkowań kształcenia uniwersyteckiego (norma), wynikających m.in. z Polskiej Ramy 
Kwalifikacyjnej, mając na uwadze realia rynkowe przyszłej kariery zawodowej studentów oraz zawarte w ogłoszeniach o pracę wymogi i oczekiwania ze strony potencjalnych pracodawców, by w końcowej części sformułować wnioski i postulaty dotyczące optymalizacji nauczania przekładu.

\section{Uwarunkowania akademickiego procesu kształcenie tłumaczy}

W procesie uniwersyteckiego kształcenia tłumaczy konieczne i uzasadnione wydaje się być zróżnicowanie dydaktyki przekładu specjalistycznego w zależności od szeregu czynników: etapu studiów, poziomu językowego studentów oraz ich wiedzy specjalistycznej, jak również w zależności od rodzaju przekładu oraz celów nauczania konkretnego kursu. Jako jeden z najważniejszych celów kształcenia translatorycznego postrzegam przygotowanie studentów do świadczenia usług tłumaczeniowych $\mathrm{z}$ zapewnieniem odpowiedniej jakości wykonywanych przekładów.

W realiach polskiego szkolnictwa wyższego istnieją rozmaite ścieżki kształcenia tłumaczy: od ogólnego przygotowania translatorskiego w ramach kierunków neofilologicznych poprzez specjalności stricte translatorskie na I i/lub II stopniu studiów aż po specjalistyczne studia podyplomowe (ukierunkowane często na wybrane dziedziny, np. przekład ustny, pisemny, specjalistyczny, poświadczony).

Obowiązujące przepisy ustawowe ${ }^{1}$ dają wybór pomiędzy dwoma profilami kształcenia: ogólnoakademickim, zakładającym powiązanie $\mathrm{z}$ prowadzonymi w uczelni badaniami naukowymi, w którym ponad połowa programu studiów ma obejmować zajęcia służące zdobywaniu pogłębionej wiedzy, oraz praktycznym, służącym zdobywaniu umiejętności praktycznych i kompetencji społecznych, przy założeniu, że ponad połowę programu studiów stanowią zajęcia praktyczne, kształtujące wspomniane umiejętności i kompetencje, w tym kursy o charakterze warsztatowym. ${ }^{2}$

Z powyższego rozróżnienia wynika, że kształcenie w ramach kierunków ogólnoakademickich - poza obowiązkowymi wakacyjnymi praktykami studenckimi - winno mieć charakter w przeważającej mierze teoretyczny. Nie sposób jednak wyobrazić sobie przygotowania do jakiegokolwiek zawodu bez systematycznego praktycznego ćwiczenia określonych umiejętności w warunkach zbliżonych do realiów rynku pracy. Biorąc pod uwagę przyszłą karierę zawodową studentów oraz istniejące umowy o partnerstwie bądź współpracy $\mathrm{z}$ przedsiębiorstwami lub innymi instytucjami regionalnymi, a także zalecane przez PKA dobre praktyki zarządzania jakością kształcenia poprzez współpracę uczelni z przedstawicielami pracodawców (PKA 2015: 35-41), wychodzę z założenia, iż wymogi rynkowe, z którymi absolwenci studiów konfrontowani są na

\footnotetext{
${ }^{1}$ Ustawa z dna 11 lipca 2014 r. o zmianie ustawy - Prawo o szkolnictwie wyższym oraz niektórych innych ustaw (Dz. U. 2014, poz. 1198).

2 Tamże, art. 1, ust. 1 a).
} 


\section{Matgorzata Jokiel: Norma i uzus $w$ dydaktyce przekladu specjalistycznego wobec oczekiwań rynku pracy}

etapie poszukiwania pracy, stanowią istotny czynnik, który również należałoby uwzględnić $\mathrm{w}$ procesie kształcenia translatorycznego. W tym kontekście nasuwa się pytanie: W jaki sposób i w jakim stopniu potencjalni pracodawcy - firmy oraz lokalne urzędy i instytucje - powinni współtworzyć programy studiów i uczestniczyć w procesie kształcenia uniwersyteckiego, aby absolwenci osiągali pożądane efekty nauczania ?

Ze względu na szczególnie istotne znaczenie gospodarki dla praktyki translatorskiej chciałabym się skoncentrować $w$ moich dalszych rozważaniach głównie na tej właśnie dziedzinie, choć zdaję sobie sprawę, że poniższe uwagi pod wieloma względami dotyczą również i innych rejestrów specjalistycznych.

\section{Miejsce języków specjalistycznych w translatoryce}

Przynależność do typu bądź rodzaju tekstu, gatunku lub też konkretnej dziedziny ma - jak powszechnie zakłada się w translatologii - istotne znaczenie zarówno dla procesu translacji, jak i oceny jakości przekładu. Zależność tę można dostrzec już choćby w najprostszym podziale tekstów na fikcyjne i użytkowe według Wernera Kollera (2001: 272). W prototypologii Mary Snell-Hornby (1994: 16-20) tłumaczenie specjalistyczne stanowi osobną kategorię obok przekładu literackiego i tzw. „ogólnojęzykowego” („gemeinsprachliches Übersetzen“). Neubert wyróżnia z kolei 4 główne typy pragmatyczne, a teksty fachowe zalicza do potencjalnie dobrze przetłumaczalnych tekstów, adresowanych zarówno do odbiorców społeczności języka źródłowego, jak i docelowego. 3 Z kolei typologia translatoryczna Kathariny Reiß (1993) koncentruje się na rodzajach tekstów, które w zależności od swojej funkcji komunikatywnej przyporządkowane są do co najmniej jednego z trzech głównych typów tekstów. Badacze tekstów specjalistycznych ${ }^{4}$ wyróżniają ponadto inne, bardziej szczegółowe poziome i pionowe podziały języków fachowych i tekstów specjalistycznych (por. np. Roelcke 2014), tego rodzaju typologie zdają się jednak mieć głównie znaczenie porządkujące, drugorzędne pod względem metodologii przekładu.

$\mathrm{Z}$ punktu widzenia tłumacza (zarówno pisemnego, jak i ustnego) centralne znaczenie ma konkretne zlecenie, które w idealnym przypadku winno określać zamierzoną funkcję przekładanego tekstu w języku docelowym i/lub okoliczności, w której tłumaczenie ma znaleźć zastosowanie. Nie mniej ważne wydaje się dokładne określenie elementów, mających wpływ na treść i formę przekładu, na przykład w oparciu o model analizy Christiane Nord (2009), uwzględniający zarówno czynniki zewnątrztekstowe (jak np. producent tekstu i jego intencje, odbiorca, medium, miejsce, czas), jak i wewnątrztekstowych (np. tematyka, treść i

3 Za Kollerem (2001: 108-109).

4 Zarys badań nad językami specjalistycznymi przedstawiają m.in. Grucza (2012) oraz Fluck (2006: 72-77). 
budowa tekstu, leksyka, składnia), by móc je w razie potrzeby stosownie zmodyfikować w zależności od zamierzonej funkcji przekładu.

Tłumacz potrzebuje ponadto szczegółowych informacji o konkretnym rodzaju tekstu źródłowego (np. list handlowy, bilans, oferta, umowa spółki, ogólne warunki handlowe - by wymienić tylko kilka przykładów z rejestru ekonomicznego), by w ten sposób móc uwzględnić konwencje kultury docelowej, a tym samym wyjść naprzeciw oczekiwaniom odbiorców.

Język ekonomiczny, podobnie jak inne języki fachowe, posiada szereg cech charakterystycznych, z którymi wiążą się określone wyzwania bądź problemy tłumaczeniowe. Do najważniejszych z punktu widzenia translacji wyróżników tekstów specjalistycznych z dziedziny ekonomii należą:5

- podobnie jak w przypadku tekstów prawniczych istnieje związek pomiędzy ustawodawstwem danego kraju, a stosowaną terminologią specjalistyczną - by wymienić choćby odmienne uwarunkowania ustawowe w dziedzinie prawa spółek,

- specyfika słownictwa specjalistycznego - ze względu na istnienie ściśle określonej terminologii $\mathrm{w}$ wielu przypadkach niemożliwe jest zastąpienie precyzyjnych terminów synonimami bądź też samodzielne stworzenie dosłownych ekwiwalentów,

- uwarunkowania gramatyczne tekstu specjalistycznego stosowanie odmiennych konstrukcji gramatycznych bądź czasów w tekście źródłowym i docelowym w konkretnych rodzajach tekstów (np. strona bierna i formy grzecznościowe w niemieckim/ strona czynna i forma 2 os. lp. w języku polskim),

- uwarunkowania kulturowe tekstu specjalistycznego - $\mathrm{np}$. implicytny bądź eksplicytny styl komunikacji, rozbieżności pod względem przyzwyczajeń i wzorców zachowań w biznesie,

- konwencje językowe związane $\mathrm{z}$ daną branżą, z jej konkretnymi poddziedzinami: handel, księgowość, bankowość, finanse oraz wariantami stylistyczno-pragmatycznymi (teksty przeznaczone dla specjalistów oraz tzw. zwykłych odbiorców, laików); różnice w makro- i mikrostrukturze tekstu (np. formy adresatywne oraz formuła pozdrowienia w listach handlowych),

- znaczący udział szeroko rozumianych tekstów ekonomicznych w ogólnej puli zleceń tłumaczeniowych uzasadnia konieczność zajmowania się tym obszarem zarówno w ramach lektoratów tekstów specjalistycznych, jak i w kształceniu tłumaczy.

Jeśli chodzi o kluczowe rozróżnienie pomiędzy dwiema zasadniczymi strategiami przekładu (egzotyzacją i udomowieniem/domestyfikacją), czyli pomiędzy przekładem ukierunkowanym na język źródłowy bądź docelowy, niemiecki badacz języków specjalistycznych Thorsten Roelcke (2010: 152153) wskazuje na dwa główne wymogi, stawiane tekstom specjalistycznym, tj. zrozumiałość i ekonomię językową, które jego zdaniem można zrealizować jedynie przy pełnym wykorzystaniu środków systemowych i

5 Cechy języka ekonomicznego opracowano w oparciu o Roelcke (2010: 150-153), uzupełnione własnymi spostrzeżeniami autorki. 


\section{Matgorzata Jokiel: Norma i uzus $w$ dydaktyce przekladu specjalistycznego wobec oczekiwań rynku pracy}

stylistycznych języka docelowego, co jednoznacznie wskazywałoby na uprzywilejowanie domestyfikacji. Stosowanie tej strategii pozwala ponadto na uwzględnienie oczekiwań odbiorców przekładu oraz konwencji kultury docelowej.

\section{Kryteria oceny jakości przekładu ustnego}

Dydaktyka przekładu nie może odbywać się w oderwaniu od kryteriów oceny jakości translacji ustnej, umożliwiających zarówno dokonywanie samooceny przez tłumacza, jak i obiektywną ewaluację osiągnięć translatorskich innych osób. W tym kontekście warto wskazać z jednej strony na często podnoszony w literaturze przedmiotu brak jednolitych kryteriów oceny jakości przekładu (zresztą nie tylko ustnego), z drugiej zaś strony wypada podkreślić złożony charakter procesu przekładu ustnego, implikujący wieloaspektowość oceny jakościowej. ${ }^{6}$

Kryteria oceny jakości przekładu niejednokrotnie różnicowane są ponadto $\mathrm{w}$ zależności od tego, czy dotyczą praktyków czy też adeptów przekładu. W odniesieniu do sytuacji dydaktycznej godne polecenia wydają się kryteria zaproponowane przez Riccardi (2001: 267-277). Autorka przeciwstawia sformułowanym przez Viezziego czterem globalnym parametrom oceny jakości przekładu profesjonalnych tłumaczy (ekwiwalencja, precyzja, adekwatność, funkcjonalność), określanym jako 'makrokryteria', szczegółowe parametry ewaluacyjne w odniesieniu do osiągnięć translatorskich studentów specjalności tłumaczeniowych ('mikrokryteria'). Do tej kategorii zaliczane są z jednej strony aspekty poprawności językowej (m.in. odstępstwa w zakresie fonologii, prozodii, leksyki, przerwy i opóźnienia w tłumaczeniu, akcent i intonacja, ewentualne błędy gramatyczne), z drugiej zaś strony kwestie związane $\mathrm{z}$ techniką przekładu i szeroko pojętymi kompetencjami translatorskimi (modyfikacja treści, informacje dodatkowe, pominięcia, zachowane rejestru specjalistycznego, umiejętność parafrazowania, opanowanie techniki notacji oraz samokontrola), jak również istotne dla procesu przekładu konsekutywnego elementy niewerbalne (utrzymywanie kontaktu wzrokowego oraz kontrola rąk).

Kautz (2000: 412-415) podkreśla $\mathrm{z}$ kolei zależność pomiędzy stosowanymi kryteriami ewaluacji jakości przekładu ustnego a perspektywą osoby oceniającej (zleceniodawcy, mówcy, słuchacza, innego tłumacza) w odniesieniu do profesjonalnych tłumaczy. W kontekście dydaktyki uniwersyteckiej badacz zwraca uwagę na konieczność uwzględnienia konkretnej sytuacji komunikacyjnej oraz na czynniki zewnętrzne, warunkujące jakość przekładu (np. dostosowanie stopnia trudności przekładanego tekstu do poziomu zaawansowania studenta, jakość tekstu

${ }^{6}$ Własny model oceny przekładu ustnego w warunkach kształcenia na uczelniach wyższych proponuje m.in. Kościałowska-Okońska (2015: 289-310) 
źródłowego, możliwość przygotowania się). Kautz wskazuje ponadto na umiejętność uzasadnienia czy też obrony zastosowanych rozwiązań translatorskich jako szczególnie istotny aspekt ewaluacji przekładu ustnego, dokonywanego przez studentów.

Współcześnie jakość tłumaczenia specjalistycznego (w odróżnieniu od przekładu literackiego) rozpatrywana jest niejednokrotnie w kontekście systemów i norm zapewniania jakości (por. np. Kalina/Ippensen 2007: 307316), tego typu modele nie dają jednak możliwości przeprowadzenia ewaluacji translacji w trakcie procesu kształcenia w sposób transparentny i przy użyciu ocen wyrażonych wartościami cyfrowymi.

\section{Tłumaczenie a vista}

Przekład a vista,7 w języku niemieckim określany jako 'Stegreifübersetzen' bądź też 'Blattdolmetschen', 'Spontanübersetzen', 'Vom-Blatt-Übersetzen', a także 'Dolmetschung vom Blatt' - dla porównania: po angielsku znany jako 'sight translation', 'at-sight translation', 'ex-tempore translation', 'oral translation's - stanowi w zależności od pozycji badawczej z reguły formę pośrednią bądź mieszaną pomiędzy przekładem pisemnym a ustnym, jako że czynność ta wykazuje zarówno pewne podobieństwa z obiema głównymi formami translacji, jak i szereg własnych cech odrębnych. Zasadniczo chodzi tu o spontaniczny przekład ustny tekstu pisanego, najczęściej dla obecnego osobiście odbiorcy, z reguły bez możliwości przygotowania się bądź też zgłębienia tematu. Tłumaczenie następuje w warunkach presji czasowej. W odniesieniu do recepcji tekstu źródłowego wymagana jest kompetencja rozumienie tekstu czytanego, w fazie produkcji tekstu docelowego szczególnie ważne stają się kompetencje retoryczne. Ciągła obecność tekstu źródłowego daje pewien nieco szerszy kontekst treści, niż ma to miejsce podczas przekładu konsekutywnego. Centralnego znaczenia nabiera komunikatywność, nie można bowiem w przypadku tłumaczenia a vista oczekiwać tej samej jakości co podczas przekładu pisemnego (akceptowalne staje się zatem np. parafrazowanie lub opisywanie nieznanych terminów fachowych bądź też interferencje składniowe), niemniej jednak ze względu na ciągłą dostępność tekstu źródłowego sytuacja tłumacza podczas przekładu a vista jest bardziej komfortowa niż podczas przekładu konsekutywnego bądź symultanicznego.

Tłumaczenie a vista stwarza zatem korzystne warunki ramowe do przeprowadzenia praktycznych ćwiczeń translacyjnych, również i w zakresie tekstów specjalistycznych, choć w kształceniu translatorycznym traktuje się je nierzadko po macoszemu, mimo iż jest istotnym elementem pośredniczącym, ułatwiającym przejście od tłumaczenia pisemnego do ustnego. Stąd też pod względem dydaktycznym godna polecenia wydaje się

\footnotetext{
7 Inne warianty nazewnictwa, występujące w terminologii polskojęzycznej, opisuje Płużyczka (2015: 41-50).

${ }^{8} \mathrm{Na}$ podstawie tabelarycznego zestawienia w Kautz (2010: 13).
} 


\section{Matgorzata Jokiel: Norma i uzus $w$ dydaktyce przekladu specjalistycznego wobec oczekiwań rynku pracy}

następująca strategia postępowania: W pierwszym etapie następuje trening techniki przekładu a vista (szybkie czytanie ze zrozumieniem, parafrazowanie, spontaniczne formułowanie pełnych zdań) na podstawie krótkich fragmentów tekstów o tematyce ogólnej (wiadomości, doniesienia prasowe). Następnym krokiem jest zastosowanie dłuższych, pełnych tekstów z rejestru prasowego. Dopiero w kolejnej fazie warto sięgnąć po teksty specjalistyczne, również $\mathrm{z}$ zachowaniem progresji ilościowej, poczynając od krótkich informacji np. z prasy specjalistycznej, jak w poniższym przykładzie:

\section{Krisenstaat: Zehn Gründe, warum Griechenland jetzt leidet}

1. Deindustrialisierung: Nach dem Beitritt zur EU 1981 erwiesen sich Produktionsstandorte in Griechenland für westliche Konzerne vielfach als überflüssig, das Land wurde eher als Absatzmarkt gesehen. Die EUOsterweiterung 2004 brachte der Textilindustrie neue Konkurrenz, mit der das Land nicht mithalten konnte. Eine Schwerindustrie fehlt in Griechenland heute fast völlig.

2. Handelsbilanz: Die Wareneinfuhren Griechenlands lagen 2008 bei 60,7 Milliarden Euro, die Warenexporte bei lediglich 17,3 Milliarden Euro. Da Tourismus und andere Dienstleistungen die Schieflage bei Weitem nicht ausgleichen, schwellen die Schulden des Landes im Ausland stark an.

3. Klumpenrisiken: Die wichtigen Wirtschaftszweige des Landes erweisen sich als wenig krisenfest. Beim Bau ging es in der ersten Jahreshälfte 2009 um 26 Prozent abwärts, beim Tourismus um 18 Prozent. Jeder fünfte Arbeitsplatz des Landes hängt jedoch direkt oder indirekt am Tourismus. Auch die Schifffahrt leidet besonders stark unter der Krise. ${ }^{9}$

Ze względu na fakt, że specyfika przekładu a vista zasadniczo wyklucza wcześniejsze przygotowanie merytoryczne, praca nad wzbogacaniem słownictwa może nastąpić po dokonaniu przekładu, bądź też poprzez stosowanie pokrewnych tematycznie tekstów źródłowych lub równoległych w różnych językach.

\section{Dydaktyka tłumaczenia konsekutywnego}

W przypadku tego rodzaju przekładu należy podkreślić rolę przygotowania do wystąpienia, w szczególności gdy chodzi o tłumaczenie jednokierunkowe dłuższych wypowiedzi, prelekcji, przemówień. Poza kompetencją translatorską koniecznymi warunkami dobrego przekładu są: znajomość tematu/dziedziny oraz słownictwa specjalistycznego, jak również ogólne przygotowanie merytoryczne, polegające na zapoznaniu się z problematyką fachową z danej branży.

Ze względu na bardziej złożony charakter przekładu konsekutywnego w porównaniu $\mathrm{z}$ tłumaczeniem a vista, celowe wydaje się $\mathrm{w}$ pierwszej kolejności ugruntowanie teoretyczne oraz zdobycie ogólnej kompetencji

9 Źródło: (http://www.manager-magazin.de/fotostrecke/fotostrecke-51717-3.html) 
translatorskiej, jak i poznanie strategii przekładu ustnego, w tym techniki notacji oraz podstaw komunikacji niewerbalnej.

Po zapoznaniu uczestników kursu z elementami teoretycznymi w następnej fazie można przejść do właściwych praktycznych ćwiczeń translatorskich, podobnie jak w przypadku przekładu a vista również $\mathrm{z}$ zachowaniem progresji jakościowej i ilościowej. W zakresie języka ogólnego w tym celu nadają się w szczególności krótkie, 3-5-minutowe przemówienia z popularnych okazji (takich jak jubileusze, urodziny, uroczyste otwarcia, powitania itp.). Każdemu wystąpieniu studenta $\mathrm{w}$ charakterze tłumacza powinna towarzyszyć autorefleksja, a następnie merytoryczna krytyka ze strony pozostałych uczestników kursu oraz osoby prowadzącej zajęcia.

Przeprowadzane spontanicznych ćwiczeń w zakresie przekładu konsekutywnego tekstów specjalistycznych w ramach zajęć uniwersyteckich uważam za bezcelowe i demotywujące. Zamiast tego proponuję model przekładu z przygotowaniem: uczestnicy kursu otrzymują z wyprzedzeniem przeznaczone do wygłoszenia teksty na dany temat wraz z opracowanym słownictwem. W ten sposób mają możliwość zapoznania się zarówno $\mathrm{z}$ tematem, jak i z samymi tekstami, przyswojenia słownictwa specjalistycznego oraz $\mathrm{w}$ razie potrzeby - samodzielnego zgłębienia tematu. Podczas zajęć prezentowane są wybrane fragmenty udostępnionych tekstów, uzupełnione o spontaniczne dodatki, wstępy, komentarze, zilustrowane prezentacjami wizualnymi. Kurs specjalistycznego przekładu ustnego ma w takim układzie dwa główne cele: po pierwsze nabywanie bądź też doskonalenie kompetencji przekładu ustnego, po drugie poszerzenie zakresu słownictwa fachowego oraz wiedzy specjalistycznej.

Tłumaczenie dwukierunkowe, zwłaszcza rozmów bądź negocjacji ze względu na swoją bliskość z językiem mówionym i mniejszą presję czasową wydaje się być zadaniem nieco latwiejszym. Wypowiedzi rozmówców odnoszą się wprost do siebie, tłumacz może ponadto zrobić użytek z dodatkowo odbieranych bezpośrednio sygnałów niewerbalnych. Zaletę tego rodzaju przekładu stanowi ponadto możliwość zadawania pytań oraz powtarzania po rozmówcach poprawnych terminów fachowych (por. Kautz 2000: 334-339). Przekład dwukierunkowy dialogowy można z powodzeniem ćwiczyć $\mathrm{w}$ ramach zajęć $\mathrm{z}$ przekładu ustnego przejmując zadane role, np.:10

1. Dwóch rektorów (Uniwersytetu Opolskiego oraz pewnego uniwersytetu $z$ obszaru niemieckojęzycznego) planuja nawiązanie wspótpracy $i$ prowadza właśnie rozmowy na temat szczegótów przyszłego partnerstwa (możliwe formy i obszary wspótpracy, wymiana studencka, perspektywy finansowania).

2. Wizyta oficjalna: rozmowy pomiędzy prezydentem Opola $i$ potencjalnego miasta partnerskiego $z$ Niemiec (rozważane formy $i$ dziedziny wspótpracy obu miast, finansowanie itp.)

10 Propozycje własne autorki. 


\section{Matgorzata Jokiel: Norma i uzus $w$ dydaktyce przekladu specjalistycznego wobec oczekiwań rynku pracy}

3. Rozmowy targowe: pewna polska firma szuka dostawcy części zamiennych do marek niemieckich $i$ prowadzi pierwsze rozmowy $z$ pewnym producentem niemieckim.

4. Pewna austriacka firma (producent produktów mlecznych) planuje wprowadzenie swoich produktów $w$ jednej z polskich sieci handlowych $i$ prowadzi właśnie rozmowy na ten temat.

Jednak w celu zapewnienia warunków, występujących w profesjonalnej działalności translatorskiej, wskazane byłoby zapewnianie studentom możliwości ćwiczenia przekładu ustnego w autentycznych sytuacjach, a nie jedynie w ramach symulacji zajęciowej. Rzeczywiste zlecenia tłumaczeniowe poza salą uniwersytecką generują bowiem dużo wyższy poziom stresu oraz powodują poddanie tłumacza, występującego przed nieznaną mu publicznością, innym kryteriom oceny. Kształcenie tłumaczy w ramach profilu ogólnoakademickiego nie nakłada jednak na uczelnię obowiązku zapewniania studentom takich możliwości. Włączanie studentów w działalność tłumaczeniową poza uczelnią należałoby zatem traktować jako dobrą praktykę, uzupełniającą fakultatywnie kształcenie w sali zajęciowej. Szczególne możliwości i ramy organizacyjne w tym zakresie obiecuje (mniej lub bardziej) sformalizowana współpraca uczelni lub jej poszczególnych jednostek z działającymi w regionie urzędami, instytucjami i firmami. ${ }^{11}$

\section{Wymogi rynkowe związane ze znajomością języka niemieckiego na podstawie ogłoszeń o pracę}

W celu ustalenia wymogów, stawianych filologom przez rynek pracy, poddano analizie 22 oferty dla absolwentów germanistyki, zamieszczone na stronie internetowej IFG UO w okresie między 25.11.2016 a 02.03.2018. ${ }^{12}$

Jak podkreślają przedstawiciele firm kooperujących z IFG UO (np. Capgemini, Atos, Stefanini, LKW Walter, Multiserwis, PwC, IBM), o wiele łatwiej jest przygotować kandydata do pracy pod względem merytorycznym niż wyposażyć go w umiejętności językowe na zadowalającym poziomie. W tym kontekście z perspektywy potencjalnych pracodawców istotniejsze staje się zatem kształcenie ogólnych kompetencji językowych w połączeniu ze znajomością rejestrów i konwencji tekstów specjalistycznych niż wiedza fachowa z określonych dziedzin, którą stosunkowo łatwo można uzupełnić pracując na określonym stanowisku. Absolwenci germanistyki najczęściej

11 Jako przykład tego typu współpracy może posłużyć udział studenci IFG Opole w charakterze tłumaczy podczas organizowanych przez lokalny urząd marszałkowski tzw. giełdach kooperacyjnych, podczas których nawiązywane są kontakty biznesowe pomiędzy przedsiębiorstwami polskimi a niemieckojęzycznymi ( $w$ szczególności z regionów partnerskich Styrii i Nadrenii PółnocnejWestfalii).

${ }^{12}$ Oferty dostępne są pod adresem: http://ifg.wfil.uni.opole.pl/oferty-pracy/ 
poszukiwani są do pracy na stanowiskach typu asystent/opiekun klienta niemieckojęzycznego, specjalista ds. pozyskiwania klientów niemieckojęzycznych, pracownik biurowy ze znajomością języka niemieckiego, a nawet pracownik wsparcia technicznego.

Do najczęściej stawianych wymogów należą: bardzo dobra/biegła znajomość języka (w mowie i piśmie), utrzymywanie kontaktów z klientami niemieckojęzycznymi (telefonicznie, mailowo, bezpośrednio), wielokanałowa obsługa klienta, udział w spotkaniach i targach zagranicznych, obcojęzyczny marketing internetowy (instagram, facebook), umiejętność pracy w zespole, zaangażowanie, umiejętności komunikacyjne, zainteresowanie zagadnieniami technicznym, chęć do nauki i samodoskonalenia. Poza obsługą podstawowych programów komputerowych rzadko stawiane są konkretne wymagania specjalistyczne. Firmy najczęściej zapewniają szkolenia na dane stanowisko pracy, a nawet opiekę mentora i możliwość zdobywania/podnoszenia kwalifikacji zawodowych.

Według oficjalnych deklaracji podpisywanie przez uczelnie umów o współpracy z przedsiębiorcami ma z perspektywy uniwersytetu umożliwić realizowanie wspólnych projektów dydaktycznych. $Z$ kolej przedstawiciele rynku pracy dostrzegają w tego typu kooperacjach np. szansę na „zbliżenie środowiska nauki ze środowiskiem praktyki gospodarczej, a poprzez to lepsze wykorzystywanie przez partnerów umowy posiadanych zasobów i potencjału", jak głosi porozumienie pomiędzy Uniwersytetem Opolskim a firmą Atos. ${ }^{13} \mathrm{~W}$ praktyce oznacza to m.in. doradztwo i konsultacje przy tworzeniu programów studiów i programów praktyki zawodowej, sprawowanie patronatu merytorycznego nad konferencjami naukowymi organizowanymi przez wydziały, a zwłaszcza umożliwienie studentom odbywanie $\mathrm{w}$ siedzibie firmy staży zawodowych. Uczelnia $\mathrm{z}$ kolei zobowiązuje się m.in. do nadania przedsiębiorcom tytułu partnera biznesowego, zapewnia możliwość udziału w konferencjach naukowych, seminariach, a także prezentacji firmy na terenie uniwersytetu. Zatem niezależnie od tego, czy dany kierunek studiów ma charakter profilu praktycznego czy ogólnoakademickiego, podpisanie umowy o współpracy między uczelnią a podmiotami zewnętrznymi daje im prawo do wpływania na programy kształcenia.

\section{Uwagi końcowe}

Jak wspomniano na wstępie, tłumaczenie ustne tekstów specjalistycznych niesie ze sobą szereg problemów i pytań, z którymi musi zmierzyć się uniwersytecka dydaktyka przekładu. Wskazane jest przede wszystkim zróżnicowanie celów nauczania, priorytetów i metod pracy w zależności od rodzaju translacji. Przy założeniu, że współczesna koncepcja uniwersytetu

${ }_{13}$ Źródło: http://www.uni.opole.pl/page/2126/porozumienie-pomiedzy-uo-a-firma-atos-podpisane 


\section{Matgorzata Jokiel: Norma i uzus $w$ dydaktyce przekladu specjalistycznego wobec oczekiwań rynku pracy}

oprócz zdobywania i pogłębiania wiedzy obejmuje również kształcenie umiejętności praktycznych i przygotowanie studentów do przyszłej pracy zawodowej, współpraca z lokalnymi przedstawicielami rynku pracy staje się nie tylko uzusem, lecz również jednym z najważniejszych współczesnych wyzwań dla uczelni wyższych. Kooperacja i otwarcie na partnerów zewnętrznych nie zmieniają jednak faktu, że za jakość kształcenia oraz treści konkretnych przedmiotów odpowiedzialni pozostają nauczyciele akademiccy. To oni powinni decydować, na ile w procesie kształcenia można/trzeba uwzględniać wymogi rynku pracy oraz wskazywać studentom możliwości uczestnictwa w aktywnościach pozauczelnianych, wspierających rozwój ich kompetencji zawodowych.

Wprawdzie przekład specjalistyczny wymaga również wiedzy merytorycznej w danej dziedzinie (por. np. Roelcke 2010: 154-155), którą najlepiej byłoby przekazywać w ramach osobnych zajęć specjalistycznych, jednak, jak wynika z przeprowadzonej analizy ogłoszeń o pracę kierowanych do absolwentów germanistyki, o wiele łatwiej jest przygotować osobę z dobrą znajomością języka obcego do pracy na stanowisku specjalistycznym niż nauczyć fachowca języka obcego na zadowalającym komunikatywnym poziomie, tym bardziej, że nie sposób automatycznie traktować filologów jako wykwalifikowanych nauczycieli wiedzy fachowej.

Niezależnie od rodzaju przekładu warto podkreślić zasadnicze $\mathrm{z}$ punktu widzenia akwizycji słownictwa specjalistycznego znaczenie pracy z tekstami równoległymi. Jednak podczas gdy w przypadku tłumaczenia a vista na pierwszy plan wysuwa się komunikatywność jako cel kształcenia, $\mathrm{w}$ związku z czym akceptowalne są na przykład parafrazy treści specjalistycznych, $\mathrm{w}$ odniesieniu do unilateralnego przekładu konsekutywnego tekstów specjalistycznych należy kłaść nacisk przede wszystkim na konieczność przygotowania merytorycznego.

W każdym wypadku permanentne dokształcanie oraz kompetencja kompensowania deficytów merytorycznych powinny być traktowane jako naczelne zasady zarówno kształcenia translatorycznego jak i zawodowej praktyki tłumaczeniowej. 


\section{Bibliografia}

Grucza, S. (2012). Fachsprachenlinguistik. Warschauer Studien zur Germanistik und zur Angewandten Linguistik. Frankfurt am Main: Peter Lang.

Fluck, H.-R. (2006). Fachsprachenforschung, w: H.G. Hönig, P. Kußmaul, P.A. Schmitt, M. Snell-Hornby (eds). Handbuch Translation. 2. Aufl. Tübingen: Stauffenburg, pp. 72-77.

Kalina S., Ippensen A. (2007). Dolmetscher unter der Lupe. Ein Bericht über neue Untersuchungen zur Dolmetschqualität, w: H.E. Jüngst, P.A. Schmitt (eds). Translationsqualität. Frankfurt am Main: Peter Lang, pp. 307-316.

Kautz, I. (2010). Stegreifübersetzen. Eine translatorische Subdisziplin. Norderstedt: GRIN.

Kautz, U. (2000). Handbuch Didaktik des Übersetzens und Dolmetschens. München: Goethe-Institut.

Koller, W. (2001). Einführung in die Übersetzungswissenschaft. 4. durchges. und aktualisierte Aufl. Wiebelsheim: Quelle \& Meyer.

Kościałowska-Okońska, E. (2015). Ocenianie. W: A. Chmiel, P. Janikowski (eds). Dydaktyka thumaczenia ustnego. Katowice: SIW, pp. 289-310.

Nord, Ch. (2009). Textanalyse und Übersetzen. Theoretische Grundlagen, Methode und didaktische Anwendung einer übersetzungsrelevanten Textanalyse. Tübingen: Julius Groos.

Płużyczka, M. (2015). Tłumaczenie a vista. Rozważania teoretyczne $i$ badania eyetrackingowe. Warszawa: Wydawnictwo Naukowe Instytutu Komunikacji Specjalistycznej i Interkulturowej, Uniwersytet Warszawski.

Polska Komisja Akredytacyjna (PKA) (2015). Wybrane dobre praktyki zarządzania jakością ksztatcenia $w$ polskich szkołach wyższych. Warszawa: Oficyna Wydawnicza ASPRA-JR.

Riccardi, A. (2001). Die Bewertung von Dolmetschleistungen während der Ausbildung und in der Berufspraxis, w: A. T. Kelletat (ed.): Dolmetschen. Beiträge aus Forschung, Lehre und Praxis. Wien: Peter Lang, pp. 267-277.

Reiß, K. (1993). Texttyp und Übersetzungsmethode: der operative Text. Heidelberg: Julius Groos.

Roelcke, T. (2010). Fachsprachen. 3., neu bearbeitete Auflage. Berlin: Erich Schmidt Verlag.

Snell-Hornby, M. (ed.) (1994). Übersetzungswissenschaft. Eine Neuorientierung. 2. Aufl. Tübingen: Francke. 